\title{
Efek Pemberian Madu terhadap Gambaran Histopatologik Aorta Tikus Wistar (Rattus norvegicus) yang Diinduksi Margarin
}

\author{
${ }^{1}$ Kurniawan Syahrul \\ ${ }^{2}$ Carla F. Kairupan \\ ${ }^{2}$ Meilany F. Durry
}
${ }^{1}$ Program Studi Pendidikan Dokter Fakultas Kedokteran Universitas Sam Ratulangi Manado ${ }^{2}$ Bagian Patologi Anatomi Fakultas Kedokteran Universitas Sam Ratulangi Manado Email: kurniawansy809@gmail.com

\begin{abstract}
Honey has various health benefits due to the antioxidant activities of two compounds namely phenolic and flavonoid. These two compounds are speculated to confer prevention and therapeutic effects on atherosclerosis. Atherosclerosis is caused by a number of factors, one of which is hyperlipidemia. This study was aimed to investigate the effects of honey administration on the histopathological features of the aorta of Wistar rats (Rattus norvegicus) induced by margarine. This was an experimental study employed 19 rats divided into four groups. Negative control (NC) group, received no treatment; positive control (PC) group, given margarine $5 \mathrm{~g} /$ day/rat for 28 days; $\mathrm{P} 1$ group, given margarine $5 \mathrm{~g} /$ day/rat and honey $2 \mathrm{ml} /$ day/rat simultanously for 28 days; and $\mathrm{P} 2$ group, given margarine $5 \mathrm{~g} /$ day/rat for 28 days followed by the administration of honey $2 \mathrm{ml} /$ day/rat for the next 7 days. Three groups NC, PC, and P1 were terminated at day 29, while P2 group was terminated at day 36. The results showed that the histopathological features of the aorta of wistar rats were normal in P1 group as well as $\mathrm{NC}$ group. On the other hand, PC and P2 groups exhibited the presence of foam cells, although the number of foam cells was fewer in P2 group compared to PC group. Conclusion: Honey exhibits preventive effects on atherosclerosis in the aorta of Wistar rats induced by margarine which was indicated by the reduction of the number of foam cells on the histopathological features of the aorta.
\end{abstract}

Keywords: honey, margarine, atherosclerosis

\begin{abstract}
Abstrak: Madu memiliki banyak manfaat karena aktivitas antioksidan yang terkandung di dalamnya, yaitu fenolat dan flavonoid. Kedua senyawa ini diduga dapat memberikan efek pencegahan dan terapi terhadap proses aterosklerosis. Aterosklerosis terjadi karena beberapa faktor, salah satunya hiperlipidemia. Penelitian ini bertujuan untuk mengetahui efek pemberian madu terhadap gambaran histopatologik aorta tikus Wistar (Rattus norvegicus) yang diinduksi margarin. Jenis penelitian ialah eksperimental, menggunakan subyek 19 ekor tikus Wistar yang dibagi dalam empat kelompok. Kelompok KN tidak diberi perlakuan; kelompok KP diberi margarin $5 \mathrm{~g} /$ hari/tikus selama 28 hari; kelompok P1 diberi margarin 5 $\mathrm{g} /$ hari/tikus dan madu $2 \mathrm{ml} /$ hari/tikus secara bersamaan selama 28 hari; dan kelompok P2 diberi margarin $5 \mathrm{~g} / \mathrm{hari} /$ tikus selama 28 hari dan dilanjutkan dengan pemberian madu 2 $\mathrm{ml} /$ hari/tikus selama tujuh hari. Tikus kelompok KN, KP, dan P1 diterminasi pada hari ke-29, sedangkan kelompok P2 diterminasi pada hari ke-36. Hasil penelitian menunjukkan gambaran histopatologik aorta tikus Wistar yang normal pada kelompok P1 sebagaimana yang terlihat pada kelompok KN. Sebaliknya pada kelompok KP dan P2, tampak adanya sel busa tapi jumlahnya lebih sedikit pada kelompok P2 dibandingkan yang terlihat pada kelompok KP. Simpulan: Madu memiliki efek pencegahan terhadap aterosklerosis pada aorta tikus Wistar yang diinduksi margarine, ditandai dengan berkurangnya bahkan tidak ditemukannya sel busa pada gambaran histopatologik aorta.
\end{abstract}

Kata kunci: madu, margarin, aterosklerosis 
Madu merupakan produk alami dari lebah yang memiliki berbagai macam manfaat bagi kesehatan yaitu aktivitas antioksidan, antimikroba, antivirus, antiparasit, antimutagenik, antitumor, dan antiinflamasi. Fenolat dan flavonoid merupakan antioksidan yang terkandung dalam madu yang juga berfungsi sebagai penangkap radikal bebas. Zat-zat antioksidan fenolat yang terdapat dalam madu efektif dan dapat menambah perlawanan tubuh terhadap stres oksidatif. Selain itu, fenolat dan flavonoid juga diduga dapat menurunkan risiko aterosklerosis. $^{1-6}$

Aterosklerosis adalah proses terjadinya penumpukan plak di dinding bagian dalam arteri yang tersusun dari lemak, kolesterol, kalsium, dan fibrin. Penumpukan plak yang terjadi secara terus-menerus akan membuat arteri menebal dan lumennya menjadi sempit sehingga dapat mengganggu aliran darah menuju organ target antara lain miokardium. Terganggunya aliran darah pada arteri akan menyebabkan keseimbangan antara penyediaan dan kebutuhan oksigen menjadi tidak stabil dan dapat membahayakan organ target yang terletak di sebelah distal dari daerah lesi. ${ }^{6-8}$ Prevalensi aterosklerosis telah dikorelasikan dengan sejumlah faktor risiko yang terbagi dalam dua kelompok, yaitu faktor risiko yang dapat dimodifikasi dan faktor risiko yang tidak dapat dimodifikasi. Hiperlipidemia merupakan salah satu faktor risiko yang dapat dimodifikasi. ${ }^{8}$

Hiperlipidemia adalah sebuah keadaan dimana terjadi peningkatan kadar kolesterol dalam plasma. Komponen kolesterol utama yang berkaitan dengan meningkatnya risiko aterosklerosis ialah kolesterol low-density lipoprotein (LDL). ${ }^{8}$ Hiperlipidemia akan menginduksi terjadinya cedera endotel sehingga terjadi reaksi kompensatorik berupa peningkatan permeabilitas endotel yang mengakibatkan terjadi penimbunan LDL di dalam tunika intima. Kolesterol LDL yang berada di tunika intima akan mengalami oksidasi oleh radikal bebas, kemudian LDL-teroksidasi tersebut akan difagosit oleh makrofag sehingga terbentuk sel busa. ${ }^{8,9}$
Margarin merupakan salah satu bahan makanan sumber lemak yang sering dikonsumsi sehari-hari. Margarin mengandung asam lemak trans yang tidak hanya dapat meningkatkan kadar kolesterol LDL, tetapi juga dapat menurunkan kadar kolesterol HDL, sehingga margarin dapat menginduksi pembentukan sel busa yang berperan dalam proses terjadinya aterosklerosis. ${ }^{10,11}$

Berdasarkan pernyataan di atas, peneliti terdorong melakukan penelitian yang bertujuan untuk mengetahui efek pemberian madu terhadap gambaran histopatologik aorta tikus Wistar (Rattus norvegicus) yang diinduksi margarin.

\section{METODE PENELITIAN}

Jenis oenelitian ini ialah eksperimental laboratorik yang dilakukan pada bulan September s/d Desember 2017 di Laboratorium Patologi Anatomi Fakultas Kedokteran Universitas Sam Ratulangi Manado. Subjek penelitian yang digunakan ialah 29 ekor tikus Wistar (Rattus norvegicus) dewasa dengan berat rata-rata 150-200 gram. Margarin yang digunakan ialah margarin curah kiloan. Margarin $5 \mathrm{~g}$ dipanaskan dan diberikan sekali sehari. Madu yang digunakan ialah madu kemasan saset (merek Halal Honey dari Halal Center Universitas Hasanuddin). Madu 0,5 ml dicampur dengan 1,5 $\mathrm{ml}$ aquades diberikan sekali sehari. Margarin dan madu diberikan secara oral dengan sonde lambung yang dibuat khusus untuk tikus.

Subjek penelitian dibagi dalam 4 kelompok. Kelompok KN (kontrol negatif), tikus tidak diberi perlakuan selama 28 hari dan diterminasi pada hari ke-29; kelompok KP (kontrol positif), tikus diberi margarin selama 28 hari dan diterminasi pada hari ke-29; kelompok P1 (perlakuan 1), tikus diberi margarin dan madu secara bersamaan selama 28 hari dan diterminasi pada hari ke-29; dan kelompok P2 (perlakuan 2), tikus diberi margarin selama 28 hari, dilanjutkan dengan pemberian madu selama 7 hari sampai hari ke-35 dan diterminasi pada hari ke-36. Pembuluh darah aorta tikus diambil dan diproses untuk pembuatan preparat histopatologik 
dan dievaluasi gambaran mikroskopiknya.

\section{HASIL PENELITIAN}

Pada tikus Wistar kelompok KN diperoleh gambaran histologik aorta yang normal. Lapisan intima, media, dan adventisia tampak normal dan tidak terdapat pembentukan sel busa. (Gambar 1).

Gambaran histopatologik aorta tikus Wistar kelompok KP memperlihatkan sel busa yang terbentuk pada tunika media aorta (Gambar 2).

Aorta tikus Wistar kelompok P1

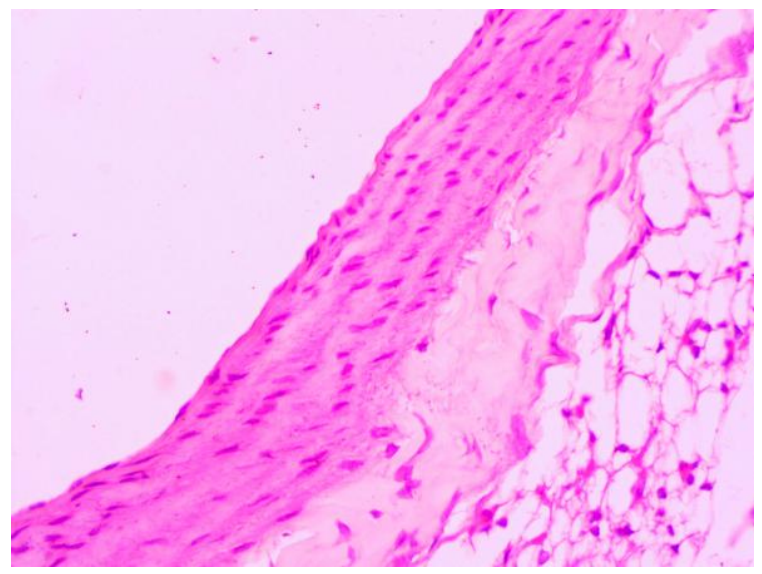

Gambar 1. Gambaran mikroskopik aorta tikus Wistar kelompok KN. Tunika intima, tunika media, dan tunika adventisia tampak normal (Pembesaran 400x)

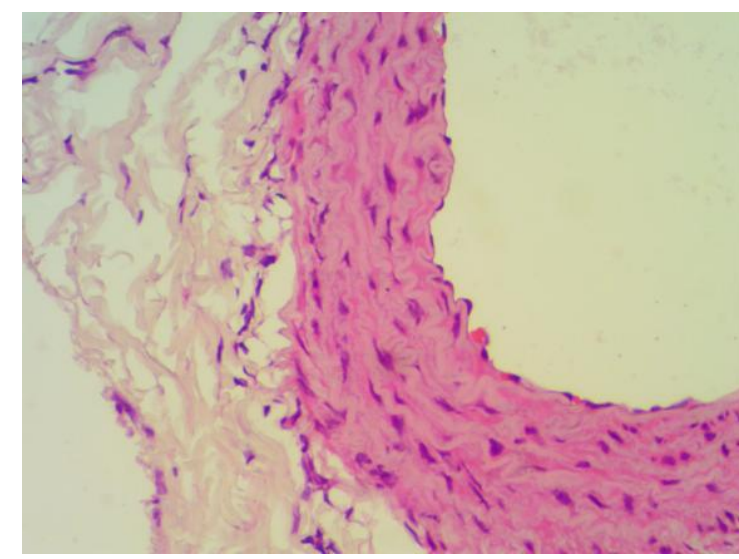

Gambar 3. Gambaran mikroskopik aorta tikus Wistar kelompok P1. Aorta tampak normal, tidak terdapat pembentukan sel busa pada ketiga lapisan dinding aorta (Pembesaran 400x) menunjukkan gambaran yang normal, tidak terdapat pembentukan sel busa pada tunika intima, tunika media, dan tunika adventisia (Gambar 3).

Pada tikus Wistar kelompok P2 diperoleh gambaran histopatologik aorta yang menunjukkan adanya sel busa pada tunika media namun dalam jumlah yang lebih sedikit dibandingkan dengan yang terlihat pada kelompok KP. Selain itu, terdapat pula bagian aorta yang menunjukkan gambaran yang normal tanpa sel busa (Gambar 4).

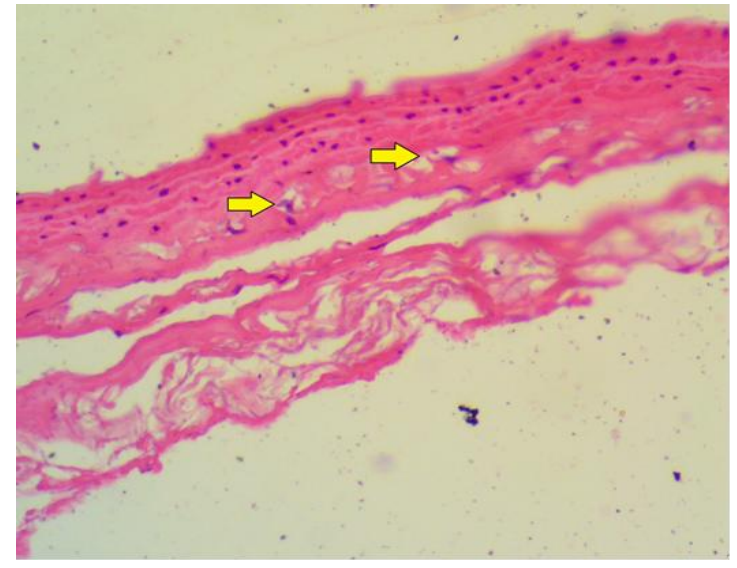

Gambar 2. Gambaran mikroskopik aorta tikus Wistar kelompok KP. Tampak sel busa (panah kuning) yang terbentuk dalam tunika media (Pembesaran 400x)

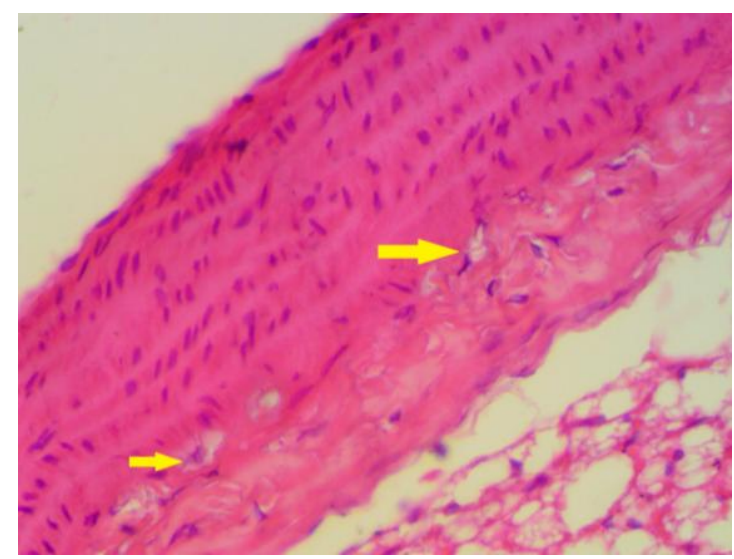

Gambar 4. Gambaran mikroskopik aorta tikus Wistar kelompok P2. Tampak adanya sel busa (panah kuning) dalam tunika media dengan jumlah sedikit (Pembesaran 400x) 


\section{BAHASAN}

Pada penelitian ini diamati efek pemberian madu terhadap gambaran histopatologik aorta tikus Wistar yang diinduksi margarin. Pemberian madu diharapkan dapat mencegah pembentukan sel busa pada kelompok perlakuan 1 dan mengurangi jumlah sel busa yang terbentuk pada kelompok perlakuan 2. Secara umum, gambaran mikroskopik aorta tikus Wistar yang diberi madu memperlihatkan adanya perbedaan jika dibandingkan dengan aorta tikus wistar yang tidak diberi madu.

Pada gambaran mikroskopik aorta tikus kelompok KP dengan pemberian margarin selama 28 hari dapat dilihat adanya sel-sel busa dalam tunika media. Gambaran ini sesuai dengan kepustakaan yang menyebutkan bahwa asupan lemak yang tinggi pada makanan mampu meningkatkan kadar kolesterol dalam darah. Margarin merupakan salah satu sumber lemak yang mengandung asam lemak jenuh, asam lemak tak jenuh, dan asam lemak trans. Konsumsi asam lemak jenuh dan trans dalam jumlah yang berlebihan akan menurunkan kadar kolesterol HDL dan meningkatkan kadar kolesterol LDL. Kadar kolesterol yang tinggi merupakan salah satu faktor risiko aterosklerosis. Berbagai faktor risiko aterosklerosis dapat meningkatkan produksi radikal bebas dalam tubuh. Peningkatan produksi radikal bebas akan menginduksi terjadinya cedera endotel. Cedera endotel yang terjadi secara kronik dapat mengakibatkan disfungsi endotel dan menjurus pada respons kompensatorik yang akan meningkatkan permeabilitas pembuluh darah serta adhesi leukosit dan trombosit terhadap endotel. Pada daerah yang mengalami peningkatan permeabilitas akan terjadi akumulasi lipoprotein terutama LDL. Low density lipoprotein yang mengalami penumpukan akan mengalami oksidasi, kemudian LDL teroksidasi tersebut difagosit oleh makrofag (scavenger reseptor) dan menjadi sel busa. ${ }^{8-10}$

Pada tikus kelompok P1 yang diberi perlakuan margarin dan madu secara bersamaan menunjukkan gambaran micros- kopik aorta yang normal., tidak didapatkan adanya sel busa baik dalam tunika intima maupun tunika media aorta. Hal ini dapat terjadi karena aktivitas antioksidan yang terkandung dalam madu, yaitu fenolat dan flavonoid. Kedua senyawa ini merupakan komponen antioksidan utama yang dapat memberikan efek protektif terhadap aorta. Fenolat memiliki aktivitas antioksidan diantaranya melalui mekanisme sebagai pereduksi, peredam terbentuknya oksigen singlet, pendonor elektron, penangkap radikal bebas dan pemutus rantai oksidatif, sehingga dapat mengurangi jumlah radikal bebas yang akan mengoksidasi LDL. ${ }^{12,13}$ Flavonoid sendiri memiliki efek protektif yaitu antitrombotik, antiiskemik, antioksidan, dan vasorelaksan. Flavonoid akan mencerna radikal bebas serta mencegah LDL mengalami oksidasi. ${ }^{14}$ Berkurangnya jumlah radikal bebas, serta dicegahnya LDL mengalami oksidasi akan menghambat pembentukan sel busa dalam tunika intima maupun tunika media aorta.

Pada kelompok P2, tikus Wistar diberikan margarin selama 28 hari, kemudian dilanjutkan dengan pemberian madu selama 7 hari. Aorta tikus Wistar pada kelompok ini menunjukkan gambaran mikroskopik yang masih memiliki sel busa, namun dalam jumlah yang lebih sedikit dibandingkan dengan kelompok kontrol positif.

Flavonoid yang terkandung dalam madu memiliki beberapa aktivitas antisklerotik, yaitu antiinflamasi, antioksidan, antiproliferasi, antiplatelet, cholesterollowering, dan antihipertensi. Terdapat banyak turunan dari flavonoid yang berperan dalam mencegah proses terjadinya aterosklerosis. Katekin, quercetin, naringenin, dan apigenin dapat menghambat oksidasi LDL. Hal ini senada dengan penelitian sebelumnya yang dilakukan untuk melihat pengaruh antioksidan madu dorsata dan madu trigona terhadap penghambatan oksidasi LDL pada mencit hiperkolesterolemia. Hasil penelitian tersebut menyatakan bahwa antioksidan yang terkandung dalam madu trigona dapat menghambat oksidasi LDL. Naringenin dan 
naringin juga menghambat ekspresi sel endotel melalui ICAM-I (hypercholesterolemia-induced-intercellular adhesion molecule-I), serta menurunkan kadar LDL dan meningkatkan kadar HDL. Turunan flavonoid lainnya seperti rutin berfungsi meningkatkan sintesis nitrit oksida (NO) yang memiliki fungsi yang sangat penting terhadap pembuluh darah seperti menyebabkan vasodilatasi, menghambat proliferasi sel otot polos, agregasi platelet, oksidasi LDL, ekspresi adhesi molekul, dan produksi endotelin. ${ }^{8,15}$ Aktivitas dari berbagai turunan flavonoid ini yang diduga berperan dalam mengurangi jumlah sel busa yang terbentuk pada tunika media dan tunika intima.

Adanya aktivitas antioksidan dari madu dapat menjadi dasar teori untuk menjelaskan hasil penelitian ini. Ternyata bahwa madu yang diberikan secara bersamaan dengan margarin dapat mencegah terjadinya pembentukan sel busa pada tunika media dan tunika intima aorta tikus Wistar. Selain itu, madu juga dapat mengurangi jumlah sel busa yang terbentuk pada bagian dinding aorta dari tikus wistar yang sudah diinduksi margarin terlebih dahulu.

Keterbatasan penelitian ini ialah jumlah sampel yang tergolong kurang pada akhir penelitian dikarenakan beberapa sampel mati saat penelitian berlangsung. Demikian pula waktu penelitian yang kurang panjang terutama dalam masa pemberian margarin dimana beberapa penelitian sebelumnya menggunakan waktu 6-8 minggu. Penetapan dosis yang diberikan terhadap sampel juga berpengaruh terhadap hasil penelitian sehingga gambaran histopatologik pada kelompok KP berupa sel busa yang terbentuk menunjukkan hasil yang kurang maksimal.

\section{SIMPULAN}

Madu memiliki efek pencegahan terhadap aterosklerosis pada aorta tikus Wistar yang diinduksi margarin yang ditandai dengan berkurangnya bahkan tidak ditemukannya sel busa pada gambaran histopatologik aorta tikus Wistar.

\section{SARAN}

Perlu dilakukan penelitian lebih lanjut untuk mengetahui bagaimana mekanisme madu dapat melindungi lapisan dinding aorta dari kerusakan akibat cedera endotel dengan dosis dan waktu yang berbeda.

Perlu dilakukan penelitian mengenai efek klinik madu terhadap penderita aterosklerosis.

Perlu dilakukan penelitian dengan analisis statistik mengenai pengaruh pemberian madu terhadap gambaran histopatologik aorta yang diinduksi bahan iritatif.

\section{DAFTAR PUSTAKA}

1. Erejuwa OO, Sulaiman SA, Wahab MSA. Honey: A novel antioxidant. Molecules. 2012;17:4400-23.

2. Rista, Yuziani. Efektivitas madu terhadap peningkatan $\mathrm{Hb}$ pada tikus putih. JESBIO. 2014;3(5):7-13.

3. Pradana DA, Hayati F, Sukma D. Pengaruh pra-perlakuan madu terhadap farmakokinetika eliminasi rifampisin pada tikus Wistar jantan. Jurnal Ilmiah Farmasi. 2013;10(1):18-28.

4. Bogdanov S, Jurendic T, Sieber R, Gallmann P. Honey for nutrition and health: a review. J Am Coll Nutr. 2008;27(6):677-89.

5. Rahma S, Natsir R, Kabo P. Pengaruh antioksidan madu dorsata dan madu trigona terhadap penghambatan oksidasi LDL pada mencit hiperkolesterolemia. JST Kesehatan. 2014;4(4):377-84.

6. Fajrilah BR, Indrayani UD, Djam'an Q. Pengaruh pemberian madu terhadap kadar malondialdehyde (MDA) plasma darah pada tikus yang diinduksi alloxan studi experimental pada tikus putih jantan galur Wistar. Sains Medika. 2013;5(2):98-100.

7. Price SA, Wilson LM. Penyakit aterosklerotik koroner. Patofisiologi: Konsep Klinis Proses-Proses Penyakit. Volume 1 (6th ed). Jakarta: ECG, 2005; p. 576-612.

8. Mitchell RN. Pembuluh darah. In: Saraswati M, alih bahasa, editor. Buku Ajar Patologi Robbins (9th ed). Singapura: Elsevier Saunders, 2015; p. 321-58.

9. Lintong MP. Perkembangan konsep patogenesis aterosklerosis. JBM. 2009; 
1(1):12-22.

10. Tuminah S. Efek asam lemak jenuh dan asam lemak tak jenuh trans terhadap kesehatan. Media Peneliti dan Pengembang Kesehatan. 2009;19(2): S13-S20.

11. Thendry A. Pengaruh pemberian ekstrak kunyit terhadap gambaran histopatologi aorta tikus Wistar (Rattus norvegicus) hiperlipidemia [Skripsi]. Manado: Fakultas Kedokteran Universitas Sam Ratulangi; 2015.

12. Chayati I, Miladiyah I. Kandungan komponen fenolat, kadar fenolat total, dan aktivitas antioksidan madu dari beberapa daerah di Jawa dan Sumatera. MGMI. 2014:6(1):11-24.

13. Ratnayani K, Laksmiwati M, Septian NPI. Kadar total senyawa fenolat pada madu randu dan madu kelengkeng serta uji aktivitas antiradikal bebas dengan metode DPPH (Difenilpikril Hidrazil). Jurnal Kimia. 2012;6(2):163-8.

14. Ibrahim KM, Amrah SS. The potential role of honey and its polyphenols in preventing heart diseases: a review. Khalil and Sulaiman Afr $\mathbf{J}$ Tradit Complement Altern Med. 2010: 7(4):315-21. 